\title{
Preconcentration of Trace Level Manganese in Blood Samples of Patients With Different Neurological Disorders Using a Deep Eutectic Solvent Extraction Method Prior to Analysis by Flame Atomic Absorption Spectrometry
}

\author{
Mariam S. Arain ${ }^{a}$, Tasneem G. Kazi ${ }^{\mathrm{a}}$, Hassan I. Afridi ${ }^{\mathrm{a}}, \mathrm{Jamshed} \mathrm{Ali}^{\mathrm{a}, *}$, and Naeemullah ${ }^{\mathrm{b}}$ \\ a National Center of Excellence in Analytical Chemistry, University of Sindh, Jamshoro 76080, Pakistan \\ ${ }^{b}$ University of Turbat, 92600 Baluchistan, Pakistan
}

\section{INTRODUCTION}

The role of transition elements in neuroscience, including manganese, has in the past decade become increasingly important with regard to their significance in main neurological disorders, i.e., Parkinson's, dementia, multiple sclerosis, and Alzheimer's $(1,2)$. $\mathrm{Mn}^{2+}$ is an essential micro-nutrient for the proper functioning of various enzymes, the nervous system, brain, and the development of the bone. It optimizes the functions of membrane transport and enzymes $(3,4)$. It also plays a vital role in biochemical and physiological processes, and deficiency or excess can lead to severe impairment, with increased levels of $\mathrm{Mn}^{2+}$ causing psychotic behavior, tiredness, lesions, headache, and other related symptoms (5). The adverse neurotoxic impact of $\mathrm{Mn}^{2+}$ on humans has been known for a long time and manifests itself in emotional lability and psychiatric symptoms, and aberrant and compulsive behavior $(6,7)$. Individuals who breathe in $\mathrm{Mn}^{2+}$ from the atmosphere show increased concentrations in their blood and have neurological complications similar to occupationally exposed people (8). Adults of $\geq 50$ years are mostly suffering from neuro disorders due to excess $\mathrm{Mn}^{2+}(9,10)$.

The determination of trace amounts of elements can be per-

\footnotetext{
*Corresponding autbor.

:E-mai: ajamsbed75@yaboo.com

Tel: +92 - 022 - 9213429

Fax: +92 - 022 - 9213431
}

\section{ABSTRACT}

An innovative preconcentration method using deep eutectic solvent extraction (DES-E) before flame atomic absorption spectrometry (FAAS) analysis is described for the first time and was used for the enrichment of trace levels of manganese $\left(\mathrm{Mn}^{2+}\right)$ in blood samples from patients suffering from different neurological disorders. The deep eutectic solvent (DES) was prepared from acetamide and zinc chloride at a different molar ratio resulting in low cost, non-toxicity, and easy availability in comparison to ionic liquids. The $\mathrm{Mn}^{2+}$ complex was formed with 1-(2- pyridylazo)2-naphthol (PAN) at pH 4-11, and entrapped in DES. Then decanol was added to enhance the extraction efficiency and feasibility for FAAS analysis. The efficiency of the DES-E method was studied and included complexing agent concentrations, $\mathrm{pH}$, DES volume, volume of decanol and hexanol, molar ratio of the components of DES, and temperature.

The enhancement factor (EF) and detection limit (LOD) were found at 42 and $0.29 \mu \mathrm{g} \mathrm{L}{ }^{-1}$, respectively. The results of the proposed method were verified by the determination of $\mathrm{Mn}^{2+}$ in a certified SRM 3132 Human Blood sample.

formed by various analytical techniques such as inductively coupled plasma atomic emission spectrometry (ICP-OES), electrothermal atomic absorption spectrometry
(ETAAS), and flame atomic absorption spectrometry (FAAS) $(11,12)$. FAAS is commonly used for elemental analysis, but it is not a good choice for trace level determination in a complex matrix of biological samples due to its lower sensitivity. Thus, it is important to develop economical and sensitive preconcentration procedures for the analysis of trace elemental levels by the common FAAS technique $(13,14)$.

Green chemistry can be defined as those methods used to decrease or eliminate hazardous substances detrimental to human health and the environment (15-18). In recent years, ionic liquids (ILs) have increasingly been used in many fields such as separation technology $(19,20)$, bio-catalysis, organic synthesis (21-23), and electrochemistry (24). The synthesis process of ILs is complex, expensive, and difficult to purify.

Therefore, the need for a simple synthetic and green alternative solvent is very important. Newly developed types of solvents include eutectic mixtures prepared from zinc salts and acetamide or mixtures having metal cations and anions in comparison to other ionic liquids with stable physical properties. These new solvents are acquired by simply mixing two constituents by self-association, often through hydrogen bond interactions. In DES formation, hydrogen bonding leads to charge delocalization where, for example, the hydrogen donor and halide ion moiety are responsible for lowering the melting point of 
the mixture relative to the melting points of the discrete components (25-27).

The distinguishing factors of DES solvents in comparison to ionic liquids are that they contain only discrete anions. The resulting DES becomes liquid at $<100{ }^{\circ} \mathrm{C}$, whereas the individual components have high melting points. Abbott et al. (25-28) investigated the eutectic combination of metal chloride and donor molecules, such as acetamide and urea, resulting in a eutectic mixture with melting points of $<150^{\circ} \mathrm{C}$. Conversion of solid zinc chloride and acetamide into a solvent has low conductivity and viscosity in comparison to other solvents with different composition (29-30).

The physico-chemical properties of DES are similar to the usual ionic liquids, except they are low cost and greener. The combination of eutectic has a low freezing point of about $150{ }^{\circ} \mathrm{C}$. Due to these extraordinary benefits, DES is now gaining more attention in the different fields of research $(31,32)$.

DESs have been extensively used for the extraction of organic solvents, dissolution of metal oxides, synthesis of nanoparticles, electrodeposition of metals, digestion of inorganic compounds, drug dissolution, $\mathrm{CO}_{2}$ absorption and purification of biodiesel, drug dissolution, and refinement of biodiesel (33-36).

The purpose of the proposed method was to synthesize a DES from a zinc chloride and acetamide mixture, and using it for the enrichment of trace amounts of $\mathrm{Mn}^{2+}$ in blood samples from neuro patients. The PAN was used as a complexforming agent and the resulting $\mathrm{Mn}^{2+}$ complex was entrapped in a DES. Decanol was added to enhance the extraction efficiency, then was easily introduced into the nebulizer of the FAAS by using a self-prepared injection system made up of a Teflon ${ }^{\circledR}$ funnel and an Eppendorf $^{\circledR}$ pipette attached to the capillary tube of the nebulizer.

\section{EXPERIMENTAL}

\section{Instrumentation}

The AAnalyst ${ }^{\mathrm{TM}} 700$ FAAS instrument (PerkinElmer, Inc., Shelton, CT, USA) was used for sample analysis. The working conditions used were in accordance with the manufacturer's recommendations. The instrumental operating parameters are listed in Table I.

\section{Chemicals and Glassware}

For the experimental work, deionized water (ELGA Lab Water System, Bucks, UK) was used. The working standards were prepared by using 1000 ppm $\mathrm{Mn}^{2+}$ (Fluka Kamica, Buchs, Switzerland). All other chemicals were of analytical grade (Merck, Darmstadt, Germany). Phosphate and acetate buffers of $0.1 \mathrm{~mol} \mathrm{~L}^{-1}$ were used to set the $\mathrm{pH}$ of the solutions. The $\mathrm{pH}$ of the samples and standards was maintained by the addition of $0.1 \mathrm{~mol} \mathrm{~L}^{-1} \mathrm{HCl}$ / NaOH solution. 1-(2-Pyridylazo)2-naphthol (PAN) was acquired from Fluka. The CRM Seronorm Trace Elements Whole Blood, LOT 1103128, was obtained from Sero AS and Bio-Rad (Milan, Italy). Zinc chloride, decanol, and hexanol were obtained from Sigma Aldrich. Acetamide was acquired from Merck. Glassware and plastics were decontaminated by soaking in 10\% $\mathrm{HNO}_{3}$ solution for 24 hours, then carefully washed with deionized water.

\section{Study Population and Sampling Protocol}

The biological samples (blood) were obtained from patients with neurological disorders, admitted as outpatients of the neurological wards at Liaquat National Hospital, Karachi \& Civil Hospital, Hyderabad. The institutional review board per-

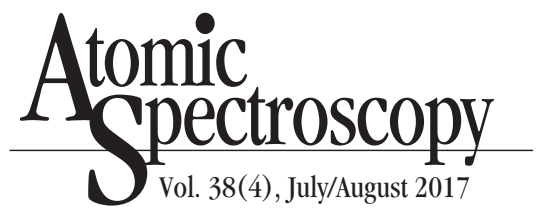

mitted this work and all patients between $50-70$ years (including their relatives used as control group, $n=60$ ) were informed of this study and gave their consent. A proforma form was developed to collect all details concerning physical data, health, dietary habit, ethnic origin, age, and consent. The blood samples were collected into metalfree safety vacutainer tubes (Becton, Dickinson and Company, Rutherford, NJ, USA).

\section{Digestion of Samples}

Duplicate blood samples of 0.5 $\mathrm{mL}$ from each study subject $(\mathrm{n}=2)$ were placed into separate PTFE flasks. The combination of nitric acid and hydrogen peroxide (2:1, $\mathrm{v} / \mathrm{v}$ ) was freshly prepared and about $2 \mathrm{~mL}$ added to each flask, then left standing at room temperature for 10 minutes. The microwave oven (Osaka, Japan) was used to oxidize all blood samples and only takes 2-3 minutes to completely oxidize the organic matrix. The digested samples were diluted to $10 \mathrm{~mL}$ with concentrated $\mathrm{HNO}_{3}$ $\left(0.1 \mathrm{~mol} \mathrm{~L}^{-1}\right)$. The details are also reported elsewhere (37). The blank digestion protocol (without sample) was carried out simultaneously.

\section{Design of DES Procedure}

\section{Preparation of Deep Eutectic} Solvents

The deep eutectic solvent (DES) was prepared in 50-mL flasks and $\mathrm{ZnCl}_{2}$ and acetamide at different ratios $(1: 1,1: 2,1: 3,1: 5)$ were

TABLE I Instrumental Conditions for FAAS

\begin{tabular}{lr}
\hline Parameters & Manganese \\
\hline Lamp Current & $2.0 \mathrm{~mA}$ \\
Wavelength & $279.5 \mathrm{~nm}$ \\
Slit Width & $0.2 \mathrm{~nm}$ \\
Fuel & Acetylene \\
Oxidant & Air \\
Background Correction & $\mathrm{D}_{2}$ Lamp \\
\hline
\end{tabular}


added. For the schematic of the DES-E method see Fgure 1. The flasks were placed on a hotplate with magnetic stirrer at the temperature and stirring rate of $75-85^{\circ} \mathrm{C}$ and $600 \mathrm{rpm}$, respectively, until a homogeneous colorless liquid was obtained, then kept standing at room temperature. The resulting DES is a biphasic system which is insoluble in water as compared with individual components (see Figure 2). The characteristics of DES are described in the literature (38-40).

\section{DES-assisted Extraction Method}

Six replicates of each standard solution $(10 \mathrm{~mL})$ containing $10-50$ $\mu \mathrm{g} \mathrm{L}^{-1}$ of $\mathrm{Mn}^{2+}$ were placed into individual conical flasks (capacity of $25 \mathrm{~mL})$. Then, $\left(1-5 \times 10^{-5} \mathrm{~mol} \mathrm{~L}^{-1}\right)$ of PAN $0.5 \mathrm{~mL}$ and $2 \mathrm{~mL}$ phosphate/ acetate buffer were added, and a $\mathrm{pH}$ range of $4-11$ was maintained with $0.1 \mathrm{~mol} \mathrm{~L}^{-1} \mathrm{HCl} / \mathrm{NaOH}$. To the contents of the flasks, DES was added in the range of $0.5-2.0 \mathrm{~mL}$ and shaken in the mechanical shaker for 2 minutes to ensure the transfer of the hydrophobic MnPAN into the DES-rich top phase. Then decanol was added in the range of $0.2-1.0 \mathrm{~mL}$. The enriched metal complex in DES was separated carefully using a syringe and subjected to FAAS analysis.

For validation, six replicate samples of acid-digested certified SRM
3132 Human Blood samples were subjected to the proposed method. The developed method at optimized parameters were applied to acid-digested duplicate samples of blood from each neuro patient and healthy male subject.

\section{Analytical Figures of Merit}

The linearity of the developed DES procedure for the enrichment of $\mathrm{Mn}^{2+}$ resulted in correlation coefficients of 0.991-0.998 with standards ranging from $10-50 \mu \mathrm{g} \mathrm{L}^{-1}$. The LOD and LOQ were calculated for $\mathrm{Mn}^{2+}$ as $0.29 \mu \mathrm{g} \mathrm{L}^{-1}$ and 0.98 , respectively, as shown in Table II. The validity of the method was verified by applying the procedure to

\section{TABLE II}

Characteristic Performance of Proposed (DES-E) Method

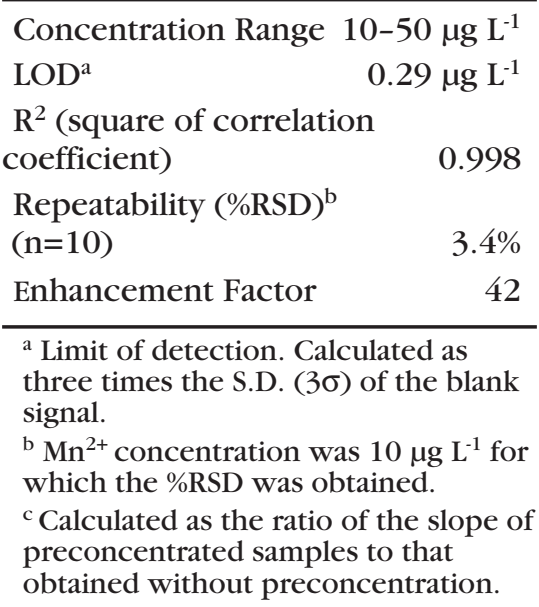

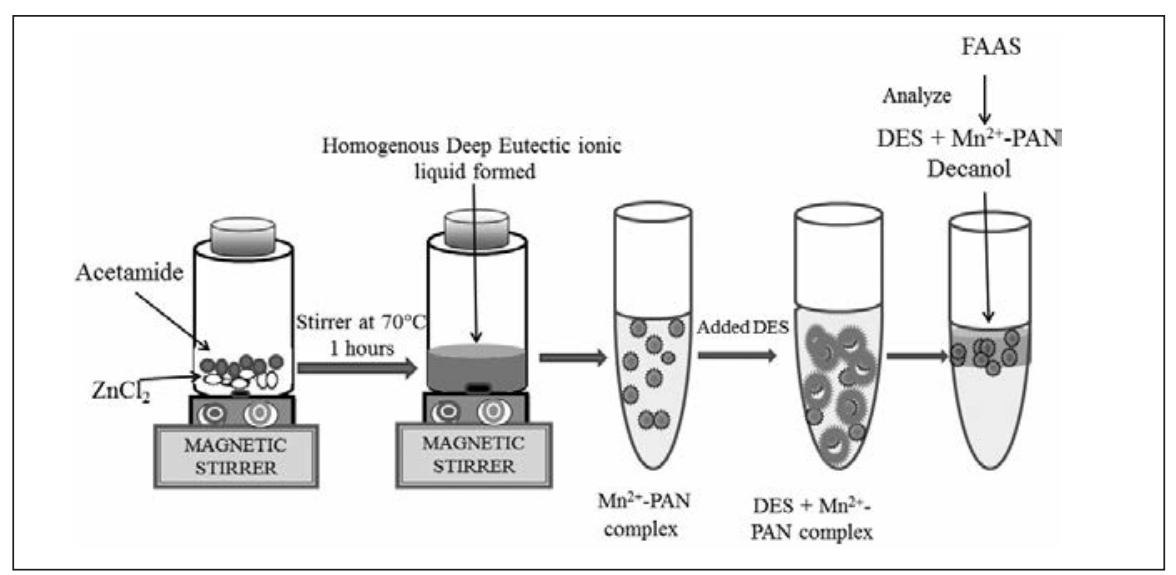

Fig. 1. Schematic of the DES-E method.
CRM SRM 3132 Human Blood and spike recovery tests by adding certified standards of $\mathrm{Mn}^{2+}$ at three concentration levels in a real sample of blood (Table III). The enhancement factor (EF) was 42. The low detection limits of the proposed DES-E procedure suggest that it is sensitive and efficient for the analysis of lower concentrations of $\mathrm{Mn}^{2+}$ in blood samples.

TABLE III

Analysis and Relative Recoveries of $\mathrm{Mn}^{2+}$ in CRM and Spiked Blood Sample Using DES-E

\begin{tabular}{lll}
\hline $\begin{array}{l}\text { CRM of } \\
\text { Blood }\end{array}$ & $\begin{array}{l}\text { Certified } \\
\text { Values } \\
\left(\mu \mathrm{g} \mathrm{L}^{-1}\right)\end{array}$ & $\begin{array}{c}\text { DES-E } \\
\text { Method } \\
\left(\mu \mathrm{g} \mathrm{L}^{-1}\right)\end{array}$ \\
\hline
\end{tabular}

SRM 3132

Human

Blood $20.7 \pm 3.15^{\mathrm{a}} \quad 20.4 \pm 2.16$

Recovery _ - $\quad 98.7 \%$

\begin{tabular}{lcc}
\hline Sample & $\begin{array}{c}\text { Added } \\
\left.\mu \mathrm{g} \mathrm{L}^{-1}\right)\end{array}$ & $\begin{array}{c}\text { DES-E } \\
\left(\mu \mathrm{g} \mathrm{L}^{-1}\right)\end{array}$ \\
\hline
\end{tabular}

Parkinson's

Patients $\quad 0$

$10 \quad 33.2$

$15 \quad 38.1$

$20 \quad 43.1$

Recovery $^{\mathrm{b}} \quad 98.1-98.6 \%$

\footnotetext{
a Mean \pm S.D.

${ }^{\mathrm{b}}$ Recovery $=\mathrm{C}_{\text {spiked }}-\mathrm{C}_{\text {unspiked }} /$ added amount $\times 100$

$\mathrm{C}_{\text {spiked }}=$ The concentration of $\mathrm{Mn}$ in blood samples after addition of Mn standard solution.

$\mathrm{C}_{\text {unspiked }}=$ The concentration of $\mathrm{Mn}$ in blood samples before addition of $\mathrm{Mn}$ standard solution.
}

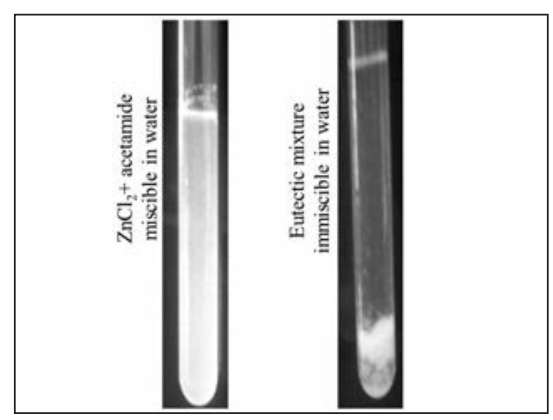

Fig. 2. Prepration and their checked miscibilty of DES in water. 


\section{RESULT AND DISCUSSION}

\section{Optimization of DES-E Method}

Some factors affect the efficiency of the DES-E method such as $\mathrm{pH}$, DES volume, chelating agent, volume of decanol and hexanol, and the molar ratio and are discussed below.

\section{Effect of pH}

The analyte forms a complex at a specific $\mathrm{pH}$, which is suitable for the complex formation and maximum extraction efficiency. Six replicate standard solutions of $\mathrm{Mn}^{2+}$ (10 $\left.\mu \mathrm{g} \mathrm{L}^{-1}\right)$ were prepared to check the influence of the $\mathrm{pH}(4-11)$ on the extraction of manganese ions. The desired effective $\mathrm{pH}$ value was acquired by adding acetate/phosphate buffer, followed by adding $0.1 \mathrm{~mol} \mathrm{~L}^{-1}$ of $\mathrm{HCl} / \mathrm{NaOH}$. The $\mathrm{Mn}$ ions form a stable complex in the range of $\mathrm{pH} 4-11$. PAN is used to form a complex with $\mathrm{Mn}^{2+}$ at the $\mathrm{pH}$ range of $4-11$. The optimum recovery of $\mathrm{Mn}^{2+}$ was achieved at pH 10 (see Figure 3), whereas at a higher $\mathrm{pH}$ the signal for $\mathrm{Mn}^{2+}$ decreases. Thus, $\mathrm{pH} 10$ was selected for $\mathrm{Mn}^{2+}$ extraction in subsequent experimental work.

\section{Effect of PAN Concentration}

For the DES-E method, PAN was used as the chelating agent. The extraction efficiency of $\mathrm{Mn}^{2+}$ as a function of PAN concentration changing from $1-5 \times 10^{-5} \mathrm{~mol} \mathrm{~L}^{-1}$ $(\mathrm{w} / \mathrm{v})$ is presented in Figure 4 . The recovery of $\mathrm{Mn}^{2+}$ is enhanced up to $4 \times 10^{-5} \mathrm{~mol} \mathrm{~L}^{-1}$ and the extraction efficiency of the metal has no significant effect by a further increase in PAN concentration. Therefore, $4 \times 10^{-5} \mathrm{~mol} \mathrm{~L}^{-1}$ of PAN was chosen for the optimum extraction of $\mathrm{Mn}^{2+}$ from the standards and real samples. PAN is an effective reagent for enrichment of $\mathrm{Mn}^{2+}$ due to its higher hydrophobic and amphiphilic properties and forms a stable complex with the study analyte (41).

\section{Effect of Molar Ratio of Eutectic Mixtures for DES}

In the present study, a eutectic mixture of $\mathrm{ZnCl}_{2}$-acetamide acid at altered molar ratios $(1: 1,1: 2,1: 3$ and 1:5) was prepared by stirring at $60-90{ }^{\circ} \mathrm{C}$ until a colorless and uniform liquid was formed. It was observed that optimum amount of solvent was formed between 75-85 ${ }^{\circ} \mathrm{C}$, so for subsequent experimental work DES was prepared at $80^{\circ} \mathrm{C}$. Different molar ratios of eutectic mixtures of $\mathrm{ZnCl}_{2}$-acetamide were used for the extraction of the hydrophobic complex of $\mathrm{Mn}^{2+}$ from certified reference standard solutions $\left(10 \mu \mathrm{g} \mathrm{L}^{-1}\right)$. Optimum recovery was obtained at the molar ratio of

\section{Atomic Apectroscopy \\ 1 Vol. 38(4), July/August 2017}

1:2 of $\mathrm{ZnCl}_{2}$-acetamide and was used for the present study. The characteristics of the prepared DES were reported elsewhere, while its formation was checked by the solubility in water. The individual component of the eutectic mixture has a high melting point, while after mixing it becomes solvent at $80{ }^{\circ} \mathrm{C}$. Both components are water soluble, but the resulting DES was immiscible in the aqueous phase (42)

\section{Effect of Deep Eutectic Solvent Volume}

The volume of the eutectic combination of $\mathrm{ZnCl}_{2}$-acetamide at the molar ratio of $1: 2$ is the chief factor for the extraction capacity of $\mathrm{Mn}^{2+}$ in acid-digested blood samples. The volume of DES used was in the range of 0.5-2.0 mL for the extraction of $\mathrm{Mn}^{2+}$. The optimum recovery of $\mathrm{Mn}^{2+}$ was achieved at $1.0 \mathrm{~mL}$ as shown in Figure 5. Therefore, 1.0 $\mathrm{mL}$ of DES was selected for further study.

\section{Effect of Decanol and Hexanol Volume}

Decanol and hexanol were used to decrease the dissolution and increase the hydrophobicity of the DES to entrap the hydrophobic chelate of $\mathrm{Mn}^{2+}$. The extraction efficiency of $\mathrm{Mn}^{2+}$ as a function of

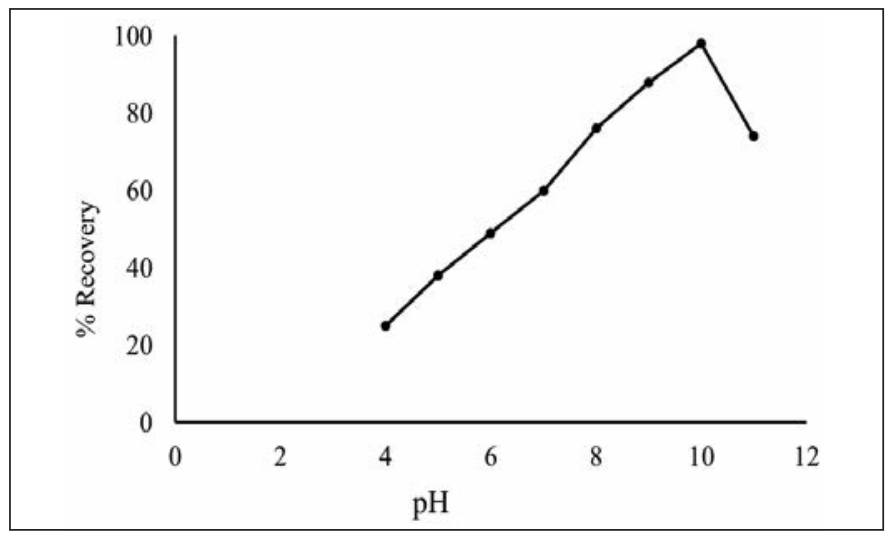

Fig. 3. Effect of $p H$ on preconcentration of $\mathrm{Mn}^{2+}$ by (DES-E) using $10 \mu \mathrm{g} \mathrm{L}{ }^{-1} \mathrm{Mn}$, PAN $4 \times 10^{-5} \mathrm{~mol} \mathrm{~L}^{-1}(\mathrm{w} / \mathrm{v}) .0 .5 \mathrm{~mL}$ of decanol, molar ratio 1:2 of $\mathrm{ZnCl}_{2}$-acetamide.

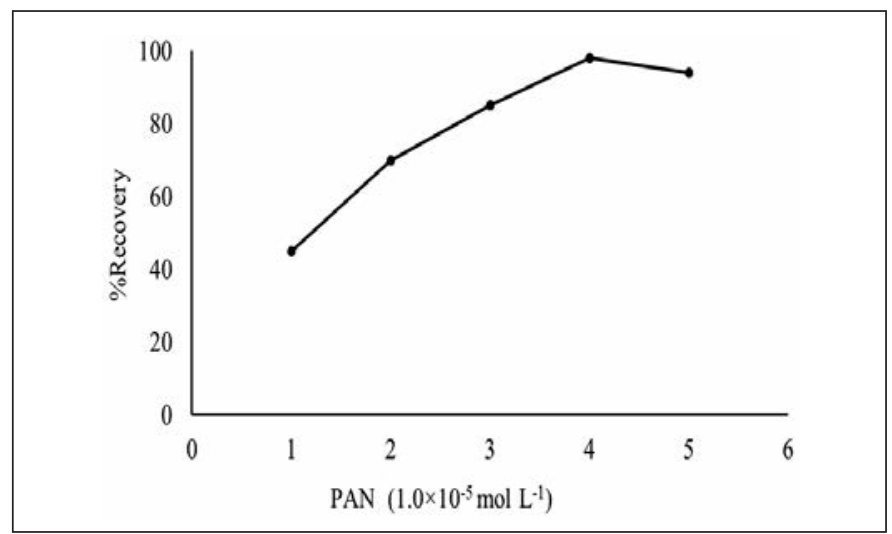

Fig. 4. Effect of PAN concentration on (\%) recovery of $\mathrm{Mn}^{2+}$ by (DES-E) using $10 \mu \mathrm{g} \mathrm{L} \mathrm{L}^{-1} \mathrm{Mn}, \mathrm{pH} 10,0.5 \mathrm{~mL}$ of decanol, molar ratio 1:2 of $\mathrm{ZnCl}_{2}$-acetamide. 
decanol and hexanol volumes ranged from $0.2-1.0 \mathrm{~mL}$, as shown in Figure 6. The recovery of $\mathrm{Mn}^{2+}$ is enhanced up to $0.5 \mathrm{~mL}$ for both solvents. A further increase in their volume caused no changes in the signals. It was seen that decanol enhanced the extraction efficiency in comparison to hexanol (15-20\%) which might be due to its higher hydrophobic nature. Hence, $0.5 \mathrm{~mL}$ of decanol was selected for the measurable extraction of $\mathrm{Mn}^{2+}$ for subsequent work.

\section{Interference Study}

The effect of background ions was also examined for the extraction of Mn ions in the sample matrix by the DES-E method. To accomplish this task, $10-\mathrm{mL}$ solutions comprising $10 \mu \mathrm{g} \mathrm{L}^{-1}$ of $\mathrm{Mn}^{2+}$ with additional interfering ions $\left(\mathrm{Na}^{+}, \mathrm{K}^{+}, \mathrm{Ca}^{2+}, \mathrm{Ag}^{+}, \mathrm{Mg}^{2+}, \mathrm{Co}^{2+}\right.$, $\left.\mathrm{Zn}^{2+}, \mathrm{Ni}^{2+}, \mathrm{Cu}^{2+}, \mathrm{Fe}^{3+}, \mathrm{Al}^{3+}\right)$ at diverse interferent-to-analyte ratios were exposed to the developed method. The amounts of coexisting ions were made as element-to-interferent ratios (w/w) of $1: 1000$ for $\mathrm{K}^{+}, \mathrm{Na}^{+} ; 1: 800$ for $\mathrm{Ca}^{2+}, \mathrm{Mg}^{2+}$; $1: 25$ for $\mathrm{Co}^{2+}, \mathrm{Zn}^{2+}, \mathrm{Ni}^{2+} ; 1: 20$ for $\mathrm{Ag}^{+}, \mathrm{Cu}^{2+} ; 1: 30$ for $\mathrm{Fe}^{3+}$ and $1: 500$ for $\mathrm{Al}^{3+}$. The commonly existing ions, such as alkaline and alkali earth metals, usually do not make a stable complex with PAN. Thus, the developed extraction method was found to be selective for Mn ions.

\section{Application}

The optimized proposed DES-E method was practiced on duplicate acid-digested blood samples from dementia, multiple sclerosis, Parkinson's patients and healthy references (mostly relatives of patients) for the determination of $\mathrm{Mn}^{2+}$. The mean concentrations with standard deviations of $\mathrm{Mn}^{2+}$ in the blood samples are listed in Table IV. The level of $\mathrm{Mn}^{2+}$ was found in the range of 15.6-18.7 $\mu \mathrm{g} \mathrm{L}^{-1}$ for the healthy references. Whereas the $\mathrm{Mn}^{2+}$ level for PD, dementia, and multiple sclerosis patients was in the range of 28.8-32.1, 23.5-26.2, and 19.5-22.7 $\mu \mathrm{g} \mathrm{L}^{-1}$, respectively. It was found that the $\mathrm{Mn}^{2+}$ levels in the blood samples of the PD patients were significantly higher than for the patients with the other two types of neurological disorders $(\mathrm{p}<0.01)$.
Despite the essential role of $\mathrm{Mn}^{2+}$ in several metabolic tasks, excessive exposure of $\mathrm{Mn}^{2+}$ gets stored in the brain which results in various neurological disorders similar to PD (43). It is well documented that the nervous system is affected by $\mathrm{Mn}^{2+}$ and is considered to show neuropsychiatric signs and extrapyramidal dysfunction $(44,45)$.

It has been reported that occupational workers and miners can have a high exposure to $\mathrm{Mn}^{2+}$. It enters the body through the respiratory tract and can seriously affect the nervous system (46). Occupational exposure to $\mathrm{Mn}^{2+}$ arises mostly due to alloy production and processing, mining, welding, ferromanganese operations and work with agrochemicals (47). In the human brain, excess $\mathrm{Mn}^{2+}$ leads to various neurological disorders such as dementia, Parkinson's disease, and multiple sclerosis (48).

The clinical features of $\mathrm{Mn}^{2+}$ neurotoxicity resemble those of

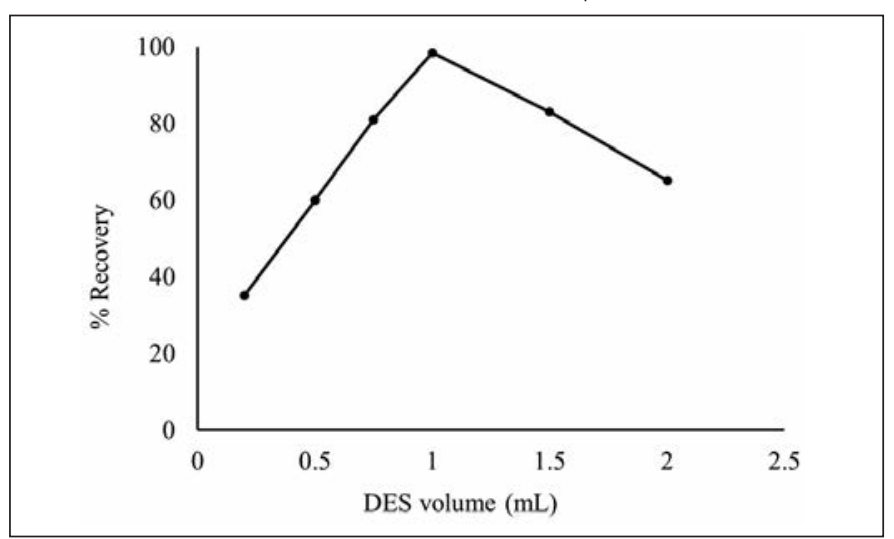

Fig. 5. Effect of DES volume on (\%) recovery $\mathrm{Mn}^{2+}$ using $10 \mu g L^{-1} \mathrm{Mn} ;$ pH 10, PAN $4 \times 10^{-5} \mathrm{~mol} \mathrm{~L}^{-1}(\mathrm{w} / \mathrm{v})$, molar ratio 1:2 of $\mathrm{ZnCl}_{2}$-acetamide.
TABLE IV

Concentration of $\mathrm{Mn}^{2+}$ in Blood Samples of Healthy References and Different Neuro Disorders in Male Patients Using DES-E Method

\begin{tabular}{lcccc}
\hline Element & $\begin{array}{c}\text { References } \\
(\mathbf{n}=60)\end{array}$ & $\begin{array}{c}\text { Parkinsons } \\
(\mathbf{n}=\mathbf{5 0})\end{array}$ & $\begin{array}{c}\text { Dementia } \\
(\mathbf{n}=\mathbf{3 0})\end{array}$ & $\begin{array}{c}\text { Multiple Sclerosis } \\
(\mathbf{n}=\mathbf{2 0})\end{array}$ \\
\hline $\mathrm{Mn}^{2+}\left(\mu \mathrm{g} \mathrm{L}^{-1}\right)$ & $17.2 \pm 1.59^{\mathrm{a}}$ & $30.5 \pm 1.58$ & $24.8 \pm 1.32$ & $21.1 \pm 1.66$ \\
\hline
\end{tabular}

${ }^{a}$ Mean \pm Standard deviation. 
idiopathic Parkinsonism (49). However, an investigation of cases of $\mathrm{Mn}^{2+}$ poisoning has revealed clinical, pharmacological, and imaging dissimilarities. Numerous interpretations have suggested the possible role of $\mathrm{Mn}^{2+}$ ions in some PD patients. Even though PD is a very communal neurological disorder in adult individuals, its etiology is still unidentified. A relation between ecological features and different inherited susceptibility, both acting during normal aging, has been suggested $(50,51)$.

\section{CONCLUSION}

A deep eutectic solvent extraction (DES-E) method was prepared from two inexpensive and harmless constituents using hydrogen bond connections by self-association, frequently to form a eutectic mixture with a melting point lower than that of each individual component. An efficient, innovative DES-E scheme has been established for the enrichment of $\mathrm{Mn}^{2+}$ in aciddigested blood samples from neuro patients before FAAS analysis. In comparison with ionic liquids, deep eutectic solvents are nontoxic, biodegradable, and easy to synthesize. The method was validated with real blood samples of neuro patients using the standard addition method. The proposed process allows the determination of $\mathrm{Mn}^{2+}$ at trace levels with good reproducibility and accuracy. The method was shown to be a good alternative to the classical ionic liquid extraction technique and avoids purification of DES and the centrifugation step. It was found that the $\mathrm{Mn}^{2+}$ levels in the blood of patients with neurological disorders was higher as compared to healthy references ( $\mathrm{p}<0.001)$. It was also observed that Parkinson's patients have high levels of $\mathrm{Mn}^{2+}$ in their blood in comparison to patients with other neurological disorders.

Received January 30, 2017.

\section{REFERENCES}

1. K.J. Barnham and A.I. Bush, Current Opinion in Chemical Biology 12, 222, (2008).

2. A.I. Bush, Metals and Neuroscience 4, 184 (2000).

3. M.S. Arain, H.I. Afridi, T.G. Kazi, F.N Talpur, M.B. Arain, A. Kazi, S.A. Arain and J. Ali, Environmental Monitoring and Assessment 187, 1 (2015).

4. J. Crossgrove and W. Zheng, NMR in Biomedicine 17, 544 (2004).

5. L. Soko, L. Chimuka, E. Cukrowska, and S. Pole, Anal. Chim. Acta 485, 25 (2003).

6. B.S. Levy and W.J. Nassetta, A Review, J. of Occupational and Environmental Health 9, 153 2003).

7. P.K. Pal, A. Samii, and D. Calne, Neurotoxicology 20, 227 (1998).

8. B. Sjögren, A. Iregren, W. Frech, M. Hagman, L. Johansson, M. Tesarz, and $\mathrm{A}$. Wennberg, Occupational and Environmental Medicine 53, 32 (1996) .

9. C.W. Olanow, Annals of the New York Academy of Sciences 1012, 209 (2004).

10. R.A. Yokel, J. of Alzheimer's Disease 10, 223 (2006).

11. F. Shah, M. Soylak, T.G. Kazi and H.I. Afridi, J. of Anal. At. Spectrom. 28, 601 (2013)

12. L. Zhao, S. Zhong, K. Fang, Z. Qian and J. Chen, J. of Hazardous Materials 239, 206,(2012).

13. M.S. Arain, S.A. Arain, T.G. Kazi, H.I. Afridi, J. Ali, S.S. Arain, K.D. Brahman and M.A. Mughal, Spectrochim. Acta Part A: Molecular and Biomolecular Spectrosc.137, 877 (2015)

14. A.R. Rod, S. Borhani and F. Shemirani, European Food Research and Technology 223, 649 (2006).

15. K.M. Erikson, T. Syversen, J.L. Aschner and M. Aschner, Environm. Toxicol. and Pharmacol. 19, 415 (2005).

16. R. Gwiazda, D. Lee, J. Sheridan and D. Smith, Neurotoxicology 23, 69 (2002).
17. M. Jahanshahi, C. Ardouin, R Brown, J. Rothwell, J. Obeso, A. Albanese, M. Rodriguez-Oroz, E. Moro, A. Benabid and P. Pollak, Brain 123, 1142 (2000).

18. C.A. Sahin, M. Efeçınar and N. Satıroglu, J. of Hazardous Materials 176, 672 (2010).

19. M. Matsumoto, K. Mochiduki, K. Fukunishi and K. Kondo, Separation and Purification Technology 40, 97 (2004).

20. G.T. Wei, Z. Yang and C.-J. Chen, Anal. Chim. Acta 488, 183 (2003).

21. S. Shah and M.N. Gupta, Bioorganic \& Medicinal Chem. Lett. 17, 921 (2007).

22. F. Favre, H. Olivier-Bourbigou, D. Commereuc and L. Saussine, Chemical Communications 1360,(2001).

23. C.E. Song and E.J. Roh, Chemical Communications 8, 37 (2000).

24. D.R. MacFarlane, M. Forsyth, P.C. Howlett, J.M. Pringle, J. Sun, G. Annat, W. Neil and E.I. Izgorodina, Accounts of Chem. Research 40, 1165 (2007).

25. A.P. Abbott, J.C. Barron, K.S. Ryder and D. Wilson, Chemistry-A European Journal, 13, 6495 (2007).

26. A.P. Abbott, G. Capper, D.L. Davies, H.L. Munro, R.K. Rasheed and V. Tambyrajah, Chemical Communications 19, 2010 (2001).

27. A.P. Abbott, G. Capper, D.L. Davies and $\mathrm{R}$. Rasheed, Inorganic Chem. 43, 3447 (2004).

28. A.P. Abbott, G. Capper, D.L. Davies, K.J. McKenzie and S.U. Obi, J. of Chemical \& Engineering Data 51, 1280 (2006).

29. M.J. Earle and K.R. Seddon, Pure and Applied Chemistry 72, 1391 (2000).

30. M.A. Kareem, F.S. Mjalli, M.A. Hashim and I.M. AlNashef, J. of Chemical \& Engineering Data 55, 4632 (2010).

31. Q. Zhang, K.D.O. Vigier, S. Royer and F. Jerome, Chemical Society Reviews 41, 7108 (2012).

32. E.L. Smith, A.P. Abbott and K.S. Ryder, Chemical Reviews 114, 11060 (2014). 
33. Q. Zeng, Y. Wang, Y. Huang, X. Ding, J. Chen and $\mathrm{K}$. Xu, Analyst 139, 2565 (2014).

34. W. Bi, M. Tian and K.H. Row, Journal of Chromatogr. A 1285, 22 (2013).

35. E. Habibi, K. Ghanemi, M. FallahMehrjardi and A. Dadolahi-Sohrab, Anal. Chim. Acta 762, 61 (2013).

36. J.D. Mota-Morales, M.C. Gutiérrez, M.L. Ferrer, I.C. Sanchez, E.A. Elizalde-Peña, J.A. Pojman, F.D. Monte and G. Luna \Bárcenas, Journal of Polymer Science Part A: Polymer Chem. 51, 1767 (2013).

37. F. Shah, T.G. Kazi, N. Ullah and H.I. Afridi, Biological Trace Element Research 153, 134 (2013).

38. A.P. Abbott, J.C. Barron, K.S. Ryder and D. Wilson, Chemistry-A European Journal 13, 6495 (2007).

39. E.L. Smith, A.P. Abbott and K.S. Ryder, Chemical Reviews 114, 11060 (2014).

40. A. Abbott, K. El Ttaib, K. Ryder and E. Smith, Transactions of the IMF 86, 234 (2008).

41. V. Doroschuk, S. Lelyushok, V. Ishchenko and $\mathrm{S}$. Kulichenko, Talanta 64, 853 (2004).

42. J. Naser, F. Mjalli, B. Jibril, S. AlHatmi and Z. Gano, International Journal of Chemical Engineering and Applications 4, 114 (2013).

43. M. Aschner, T.R. Guilarte, J.S. Schneider and W. Zheng, Toxicology and Applied Pharmacology 221,131 (2007).

44. C.J. Martin, Neurotoxicology 27, 347 (2006).

45. J.E. Myers, M.L. Thompson, S. Ramushu, T. Young, M.F. Jeebhay, L. London, E. Esswein, K. Renton, A. Spies and A. Boulle, Neurotoxicology 24, 885 (2003).

46. M. Verity, Neurotoxicology 20, 489 (1998).

47. J.S. Schneider, E. Decamp, A.J. Koser, S. Fritz, H. Gonczi, T. Syversen and T.R. Guilarte, Brain Research 1118, 222 (2006).

48. B. Racette, L. McGee-Minnich, S. Moerlein, J. Mink, T. Videen and J. Perlmutter, Neurology 56, 8 (2001).
49. P. Zatta, R. Lucchini, S.J. van Rensburg and A. Taylor, Brain Research Bulletin 62, 15 (2003).

50. M. Aschner and M. Gannon, Brain Research Bulletin 33, 345 (1994).

51. J.A. Firestone, J.I. Lundin, K.M. Powers, T. Smith \Weller, G.M. Franklin, P.D. Swanson, W. Longstreth and H. Checkoway, American Journal of Industrial Medicine 53, 217 (2010). 